\title{
Aggravating and Protecting Effects of Triton and Prednisolone in Galactosamine Induced Hepatitis ${ }^{1}$ )
}

\author{
By P. J. Grases'1), R. Lesch, U. Stein, H. Heissmeyer and W. Reutter \\ Patbologisches Institut, Medizinische Universitätsklinik und Biochemisches Institut, \\ Universität Freiburg, Freiburg/Germany'
}

(Eingegangen am 20. April/3. August 1972)

The biochemical and morphological modifications that Triton and prednisolone produce on galactosamine hepatitis in rats were studied. Determinations of acid phosphatase, $\mathrm{N}$-acetyl- $\beta$-glucosaminidase, cathepsin $\mathrm{D}$, and acid carboxypeptidase in tissue fractions indicate that they can be liberated from lysosomes when galactosamine and Triton are given either alone or simultaneously; in the latter case the alterations are more severe. - Prednisolone not only inhibits the changes produced by galactosamine, but it is also capable of inhibiting marked elevation of the serum levels of aspartate and alanine transaminase and of sorbitol dehydrogenase, and of morphologic signs of liver damage.

In der vorliegenden Arbeit werden bei der Galaktosamin-Hepatitis biochemische und morphologische Veränderungen beschrieben, die durch die Verabreichung von Triton WR-1339 beziehungsweise Prednisolon hervorgerufen werden. - Durch Bestimmung der sauren Phosphatase, N-Acetyl- $\beta$-glucosaminidase, Kathepsin D und sauren Carboxypeptidase in Lysosomenfraktionen konnte sowohl durch Triton WR-1339 als auch durch Galaktosamin eine Labilisierung der Lysosomenmembran nachgewiesen werden. Gleichzeitige Gabe von Galaktosamin und Triton WR-1339 führt zu einer verstärkten Labilisierung lysosomaler Membranen. — Nach vorheriger PrednisolonGabe reagiert. die Leber nach Galaktosamin-Gabe nur mit einer gering ausgeprägten Entzündung: die Aktivitäten der Aspartat- und Alanintransaminase sowie Sorbitdehydrogenase im Plasma steigen nur wenig an; lichtmikroskopisch zeigt sich eine geringe entzündliche Infiltration ohne Nekrosen. Wird Prednisolon nach der Galaktosamin-Applikation gegeben, tritt die Hepatitis abgeschwächt auf.

As in other experimental hepatocellular damages $(1,2)$ galactosamine hepatitis is characterized by the presence of structural alterations in more than one organelle $(2,3,4)$. The difficult task of establishing the so called "primary target organelle" has so far been accomplished with only a few toxic agents $(5,6)$. An increase of catabolic lysosomal enzyme activities in the rat liver can be observed after administration of galactosamine (7), and for this reason, it was of interest to study the possible role of lysosomes in this type of liver injury by the application of compounds which can produce labilization and injury $(8,9,10)$ or stabilization (11) of lysusomes.

The present study deals with morphological and biothemical findings, obtained by application of Triton WR-1339 and prednisolone to rats with acute galactosamine hepatitis. Triton was used because of its capacity for increasing lysosomal fragility (12), and prednisolone, because of its well known lysosomal stabilizing effect (11) and its ability to arrest the development of experimental hepatic disease $(13,14)$.

\section{Materials and Methods}

\section{Animals}

Male Wistar rats (Ivanovas, Kisslegg, Germany) were fed a standard diet (Altromin R; Altromin GmbH, Lage, Germany) and water ad libitum. The animals were divided into two experimental groups:

1) Instituto Anatomopatológico, U. C. V., Caracas, Venezuela. Recipient of an Alexander von Humboldt-Stiftung Postdoctoral Research Fellowship.

\section{Group I}

In this group the body weights ranged between 150 and $160 \mathrm{~g}$, and the animals were divided into the following subgroups ${ }^{2}$ ):

A) GalN (4 rats) - a single dose of an aqueous solution $(0.45 \mathrm{~mol} / \mathrm{l})$ of galactosamine (purchased as D-galactosamine $\cdot \mathrm{HCl}$ by Carl Roth OHG, Karlsruhe, Germany) was injected intraperitoneally at a level of $375 \mathrm{mg} / \mathrm{kg}$;

B) Triton (4 rats) $-1 \mathrm{ml}$ of a Triton WR-1339 (Serva, Heidelberg, Germany) solution diluted in saline to a concentration of $200 \mathrm{mg} /$ $\mathrm{ml}$, was injected into the tail vein;

C) GalN plus Triton (9 rats) - galactosamine and Triton were given simultaneously in the previously mentioned amounts;

D) Prednisolone (4 rats) $-0.15 \mathrm{ml}$ of an aqueous solution of prednisolone (Deltacortril-Pfizer $\mathrm{GmbH}$, Karlsruhe, Germany) containing $10 \mathrm{mg} / \mathrm{ml}$ were given 4 times intravenously at $3 \mathrm{~h}$ intervals;

E) GalN plus prednisolone (4 rats) - the first dose of prednisolone was given immediately after galactosamine and the amounts, routes of administration and subsequent treatment were the same as stated above;

F) Controls (11 rats) - no treatment

\section{Group II .}

In this second group, the animals weighed between 180 and $200 \mathrm{~g}$ and were also divided into 6 equivalent subgroups. Each subgroup contained 6 rats with the exception of the GalN plus Triton subgroup which contained 7. The experiment was designed in the same way as in Group I, but prednisolone was given subcutaneously at slightly higher dose (up to $0.2 \mathrm{ml}$ ). In the GalN plus prednisolone subgroup prednisolone was also administered for one day before galactosamine injection $(0.2 \mathrm{ml} \times 4$ at 3 -hour intervals).

2) The number of rats indicated in each subgroup corresponds to those in which total activities of acid phosphatase and N-acetyl- $\beta$ glucosaminidase were determined. The numbers in which other enzymes were studied are given in Table 2. 
An additional subgroup of 7 rats treated with galactosaminc and 10 rats with combined GalN plus prednisolone treatment as previously described, was included for determination of serum enzyme levels.

After $24 \mathrm{~h}$ without food but with water, the rats were killed by exsanguination under light ether anaesthesia. The livers were removed and divided into several portions for light microscopic examination and biochemical enzyme determinations.

\section{Light microscopy}

Tissue fragments were fixed in $4 \%$ neutral buffered formalin and paraffin sections were stained conventionally with hematoxylin and eosin, PAS, and PAS after diastase treatment.

\section{Biochemical enzyme determinations}

Total activities were determined in liver homogenates prepared by homogenizing the samples $(0.6-1.5 \mathrm{~g})$ with 9 volumes of distilled water in an Ultraturrax homogenizer (Jahnke und Kunkel, Staufen, Germany).

Tissue fractionation studies were done according to the principles given by de Duve et al. (15) modified by Platt and KatzenMEIER (16). Before biochemical study samples were frozen and thawed 3 times.

Acid phosphatase (EC 3.1.3.2) was determined according to the method described by GIANETto and DE Duve (17) but with addition of Triton X-100 as proposed by Watriaux and DE Duve (18). The liberated inorganic phosphate was measured following the principle described by FISKE and SubBarow (19).

$N$-Acet)l- $\beta$-glucosaminidase (EC 3.2.1.30) was estimated by the method of VAES and JAQUES modified by vaN Hoof and Hers (20).

Cathepsin D (EC 3.4.2) was measured by the method of ANSON (21).

Acid carboxypeptidase (EC 3.4.2.1) was determined as described by BUDDECKE et al. (22) using the technique proposed by MATHESON and TATTRIE (23).

One unit of hydrolytic activity represents the amount of enzyme needed to degrade 1 micromole of substrate per minute at $37^{\circ} \mathrm{C}$ (20). Protein was measured by means of the Biuret technique (24). Standard procedures were used for determination of serum levels of aspartate aminotransferase (EC 2.6.1.1) (25), alanine aminotransferase (EC 2.6.1.2) (26) and sorbitol debj'drogenase (EC 1.1.1.14) (27). Histological examination was performed in all animals. Determinations of cathepsin $D$ and acid carboxypeptidase were only done in rats from experimental Group I. Total activities of acid phosphatase and $\mathrm{N}$-acetyl- $\beta$-glucosaminidase were also determined in this group and repeated when fractionation studies of these two enzymes were done in experimental Group II.

\section{Results}

\section{Light microscopic study}

The histological findings were similar in both groups. In the galactosamine treated subgroups the usual findings were noted: mainly disseminated single cell and spotty necroses; activation of mesenchymal cells, and inflammatory infiltrates not only in the parenchyma, but also in the portal tracts (Fig. 1a).

The hepatocytes of Triton-treated animals showed no alterations. The KupFFer cells were moderately increased in number but no evidence of erythrophagocytosis was found.

The animals given galactosamine plus Triton displayed the most severe hepatic lesions. Although the lobular architecture was preserved, the areas of parenchymal necroses were extensive and inflammatory cells were more numerous than with galactosamine alone (Fig.
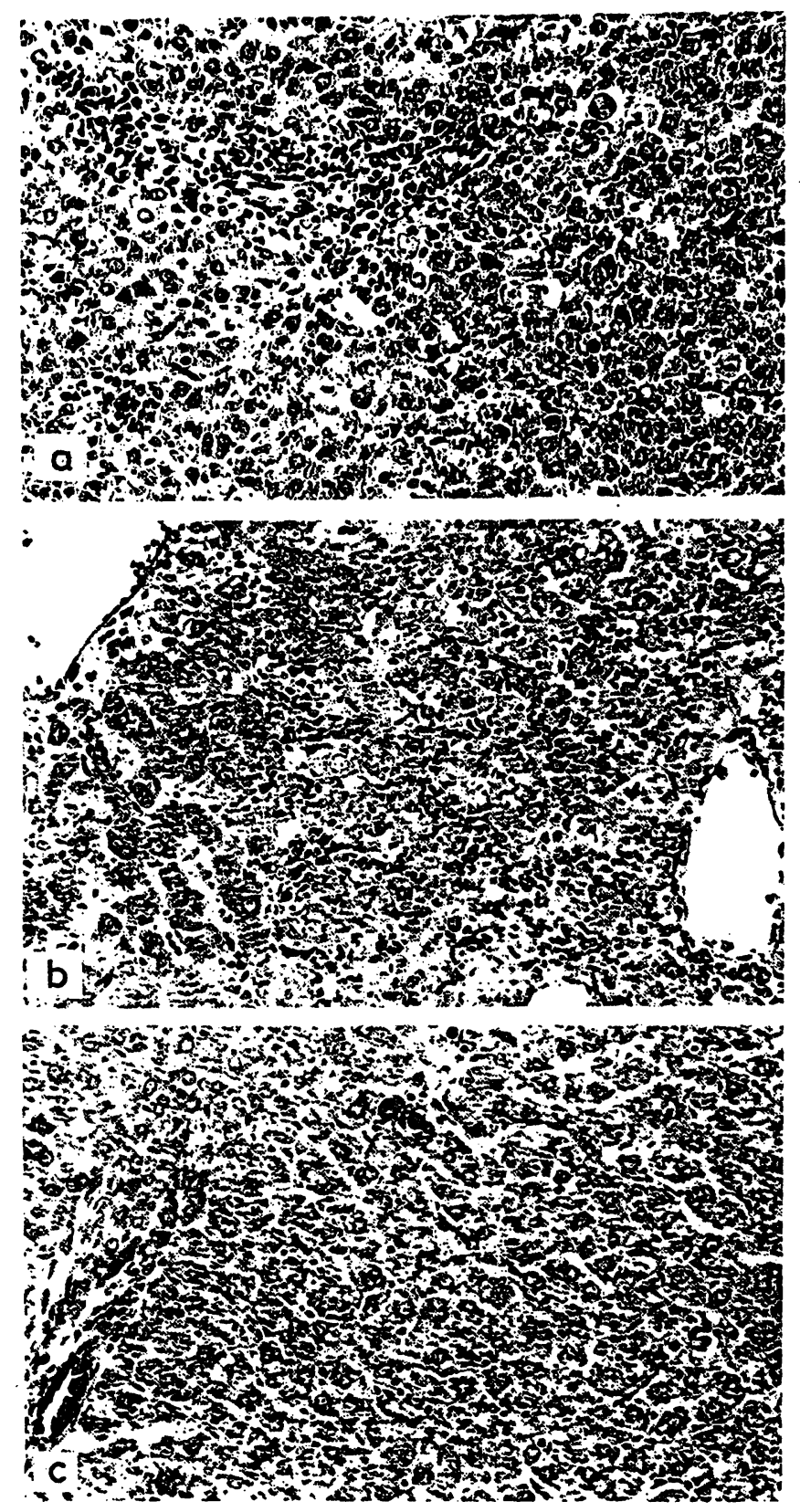

Fig. $1 \mathrm{a}$

Liver of rat $24 \mathrm{~h}$ after administration of galactosamine. Hematoxylin and eosin. $\times 125$

Fig. $1 \mathrm{~b}$

Liver of a galactosamine plus Triton-treated rat. Extensive parenchymal necroses and numerous inflammatory cells are evident Hematoxylin and eosin. $\times 125$

Fig. 1c

Liver of a galactosamine plus prednisolone-treated rat. Single cell absence of inflammatory cells. Hematoxylin and eosin. $\times 125$

1b). Conspicuous edema of the portal tracts as well as focal parenchymal hemorrhages appeared as additional features.

When prednisolone was given in addition to galactosamine, the lesions were similar to those present in the galactosamine-treated.animals, but much less marked (Fig. 1c). Entire lobules free of necroses could be identified. Variations in hepatocytic size and shape, as well as variations in the staining quality of the cytoplasm, were less conspicuous. No differences could be detected between the animals pretreated with predni- 
solone (Group II) and those without previous administration of the corticosteroid (Group I).

The prednisolone-treated subgroups showed fine vacuolated fatty degeneration, limited mostly to the lobular periphery.

\section{Biochemical enzyme determinations}

Serum levels of aspartate, and alanine transaminase, and of sorbitol dehydrogenase of those animals treated with gelactosamine plus prednisolone were much lower than those present in the animals treated with galactosamine alone (Tab. 1). Mean values for the three enzymes were almost normal.

Total activities of cathepsin D and acid carboxypeptidase were decreased in the animals treated with galactosamine. Both catabolic enzymes were increased in the supernates from the rats in which galactosamine plus Triton were given. Elevations of enzyme activities were also present in the supernates from the galactosaminetreated rats. When Triton was injected alone, only cathepsin D was increased (Tab. 2).

In experimental Group II total activities of acid phosphatase and $\mathrm{N}$-acetyl- $\beta$-glucosaminidase, whether rel-

Tab. 1

Serum enzyme activities $[U / 1]^{2}$

\begin{tabular}{lcccc}
\hline Treatment & $\mathbf{n}$ & $\begin{array}{c}\text { Aspartate } \\
\text { transaminase }\end{array}$ & $\begin{array}{c}\text { Alanine- } \\
\text { transaminase }\end{array}$ & $\begin{array}{c}\text { Sorbitol } \\
\text { dehydro- } \\
\text { genase }\end{array}$ \\
\hline $\begin{array}{l}\text { GalN } \\
\text { GalN + Predni- } \\
\text { solone }\end{array}$ & 7 & $1258 \pm 528$ & $667 \pm 365$ & $353 \pm 168$ \\
\hline a $\overline{\mathbf{x}} \pm \mathrm{s}$ & 10 & $85.3 \pm 21.9$ & $23.5 \pm 6$ & $8.0 \pm 6.6$ \\
\hline
\end{tabular}

Tab. 2

Liver enzyme activities

\begin{tabular}{|c|c|c|c|c|c|c|}
\hline & \multirow[b]{2}{*}{ Subgroup } & \multirow[b]{2}{*}{$\mathbf{n}$} & \multicolumn{2}{|c|}{ Cathepsin D } & \multicolumn{2}{|c|}{ Acid carboxypeptidase } \\
\hline & & & $\begin{array}{c}\text { Total } \\
{[\mathrm{mU} / \mathrm{g}]} \\
\overline{\mathbf{x}} \pm \mathrm{s}\end{array}$ & $\begin{array}{c}\text { Supernate } \\
\text { [mU/mg Protein] } \\
\overline{\mathbf{x}} \pm \mathrm{s}\end{array}$ & $\begin{array}{c}\text { Total } \\
{[\mathrm{mU} / \mathrm{g}]} \\
\overline{\mathbf{x}} \pm \mathrm{s}\end{array}$ & $\begin{array}{c}\text { Supernate } \\
\text { [mU/mg Protein] } \\
\overline{\mathbf{x}} \pm \mathrm{s}\end{array}$ \\
\hline$\cdot$ & $\begin{array}{l}\text { Control } \\
\text { GalN } \\
\text { Triton } \\
\text { GalN + Triton } \\
\text { Prednisolone } \\
\text { GalN + Prednisolone }\end{array}$ & $\begin{array}{l}4 \\
4 \\
4 \\
3 \\
4 \\
4\end{array}$ & $\begin{array}{l}246 \pm 15.3 \\
155 \pm 19.6^{b} \\
246 \pm 42.5 \\
242 \pm 45 \\
212 \pm 30.4 \\
218 \pm 43.7\end{array}$ & $\begin{array}{l}0.66 \pm 0.04 \\
1.14 \pm 0.23^{a} \\
1.26 \pm 0.17^{b} \\
1.48 \pm 0.09^{a} \\
0.50 \pm 0.11 \\
0.59 \pm 0.09\end{array}$ & $\begin{array}{l}649 \pm 84 \\
410 \pm 75.4^{2} \\
696 \pm 105 \\
557 \pm 93 \\
721 \pm 145 \\
630 \pm 82.5\end{array}$ & $\begin{array}{l}0.66 \pm 0.08 \\
1.64 \pm 0.14^{c} \\
0.58 \pm 0.06 \\
1.93 \pm 0.13^{c} \\
0.58 \pm 0.06 \\
0.76 \pm 0.11\end{array}$ \\
\hline
\end{tabular}

p of paired samples (vs controls) $a<0.01 ; b<0.0025 ; c<0.0005$

Tab. 3

Liver enzyme activities

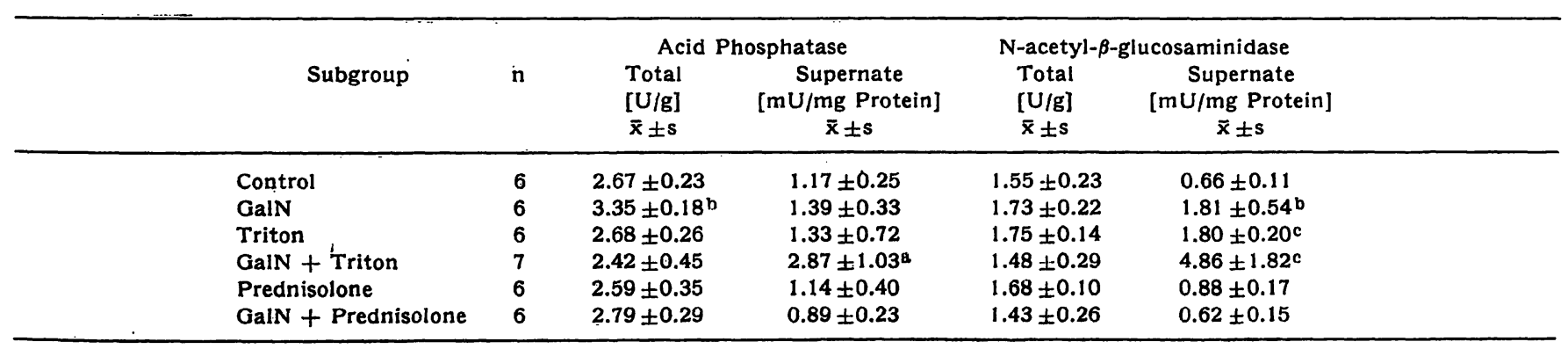

$\mathrm{p}$ of paired samples (vs controls) $\mathrm{a}<0.005 ; \mathrm{b}<0.0025 ; \mathrm{c}<0.0005$

ated to protein content or wet weight, showed similar values with exception of an increase of acid phosphatase in the galactosamine-treated rats. Both enzymes were elevated in the supernates from the GalN plus Triton-treated subgroup, but only $\mathrm{N}$-acetyl- $\beta$-glucosaminidase showed increased acitivity in the supernates from the animals treated with galactosamine alone or Triton alone (Tab. 3).

In both groups, enzyme activities of the combined galactosamine plus prednisolone treatement were comparable to those found in the control animals.

\section{Discussion}

The present study indicates that Triton WR-1339 is capable of aggravating the lesions produced by galactosamine in the liver of rats. It also suggests that a protective effect can be obtained by administering prednisolone either simultaneously or before giving galactosamine.

Total activities of the lysosomal enzymes acid phosphatase, $\mathrm{N}$-acetyl- $\beta$-glucosaminidase, cathepsin $\mathrm{D}$, and acid carboxypeptidase in the liver homogenates were determined on the premise that lysosomal damage induced by galactosamine or galactosamine plus Triton would liberate lysosomal enzymes. Only cathepsin D and acid carboxypeptidase were found to be decreased in the galactosamine treated animals, but acid phosphatase was increased in the same subgroup.

The use of fractionation techniques demonstrates that the significant increase of several enzymes in the majority of supernates from those animals treated with galactos- 
amine and/or Triton reflect the release of enzymes from lysosomes. This confirms previous findings in which cathepsin D and acid carboxypeptidase showed similar changes $25 \mathrm{~h}$ after the administration of galactosamine (7). An increase in lysosomal enzyme activities in the liver is not due to an enhanced activation of mesenchymal cells, because normal enzyme values could be measured in liver diseases with mesenchymal activation, and also in isolated leucocytes stimulated by inflammation $(28,29)$.

Whether the liberation of these enzymes is the result of primary damage already present in the early stages of liver injury, or is only an expression of cell necroses (8), is difficult to establish in this experiment. But in any case, the increase of 3 of the 4 assayed enzymes in the supernates from those animals treated with Triton alone cannot be attributed to focal necroses or to the concurrence of an extrahepatic cell population, since neither necroses nor inflammatory infiltrates were observed.

The absence of enzyme variations in the animals treated with galactosamine and prednisolone indicates that corticosteroids have a protective role. Furthermore, the impressive inhibition of an increase of serum levels of aspartate and alanine transaminase and of sorbitol dehydrogenase observed when prednisolone is given together with galactosamine constitutes additional evidence for the protective role of prednisolone. To what degree this protection is achieved with participation of other organelles, including the cell membrane, is not known with certainty $(11,30)$. The stabilizing effect of corticosteroids in connection with lysosomes has been demonstrated in the liver but without any relation at all to toxic agents (31), and in in vitro experiments (30). Confirmatory evidence based on the antagonistic effects of vitamin $A$ and cortisone indicate that this çan also be accomplished in vivo (32).

The increase in total activities of acid phosphatase after administration of galactosamine alone may suggest new synthesis as the result of an early 'regenerative response to the diffuse damage (28). Increased synthesis of $\mathrm{N}$ acetyl- $\beta$-glucosaminidase, suggested to be the consequence of parenchymal cell division, has been found in rats $24 \mathrm{~h}$ after partial hepatectomy (33).

If the aggravating effect of Triton on the hepatic necroses induced by galactosamine is due at least partially to lysosomal injury, it would seem to support the assumption that alterations of this organelle play a role in the conversion of spotty viral hepatitis to massive hepatic necroses (10). On the other hand further studies of the protective role of corticosteroids using galactosamine induced hepatitis as an experimental model might be useful in order to clarify the inconsistency in the response of human viral hepatitis to corticosteroid therapy.

\section{Acknowledgments}

The authors wish to express their gratitude to Miss Barbara Hassers and Miss Craudia Gentner for their skillfull technical assistance.

This investigation was supported by Deutsche Forschungsgemeinschaft, Bonn-Bad Godesberg and Wissenschaftliche Gesellschaft, Freiburg.

\section{References}

1. SchaffNer, F. (1966), Medicine 45, 547-552. - 2. Medinine, A., Schaffner, F. \& Popper, H. (1970), Exp. Molec. Pathol. 12, 201-211. - 3. Reutter, W., Lesch, R., KeppleR, D. \& DeCKER, K. (1968), Naturwiss. 55, 497. - 4. KeppleR, D., LesCH, R., Reutter, W. \& Decker, K. (1968), Exp. Molec. Pathol. 9, 279-290. - 5. Novikoff, A. B., Roheim, P. S. \& Quintana, N. (1966), in Biochemical Pathology (Farber, E. \& Magee, D. F., eds.) p. $27-49$, Williams \& Wilkins, Baltimore, Maryland. 6. Recknagel, R. O. (1967), Pharmacol. Rev. 19, 145-208. 7. Stein, U., Heissmeyer, H., Wangemann, G., Lesch, R., Reutter, W. \& Keppler, D. (1971), Klin. Wschr. 49, 550-554. 8. Slater, T. F. (1969), in Lysosomes in Biology and Pathology (Dingle, J. T. \& Fell, H. B., eds.) Vol. I, 469-492, NorthHolland Publishing Co., Amsterdam \& London. - 9. Roels, O. A. (1969), in 1. c. (8) Vol. I, 254-275. - 10. Iturriaga, H., Posalaki, I. \& Rubin, E. (1969), Exp. Molec. Pathol. 10, 231239. - 11. WerssmanN, G. (1969), in 1. c. (8) Vol. I, 276-295. 12. Wattiaux, R., Wibo, M. \& Baudhun, P. (1963), in Lysosomes (de Reuck, A. V. S. \& Cameron, M. P. eds.) 176-196, Ciba Foundation Symposium, Little Brown, Boston. - 13. HurTERER, E., Rubin, E., Gall, E. \& Popper, H. (1962), Exp. Molec. Pathol. 1, 85-95. - 14. Anthony, D. D., Schaffner, F., Popper, H. \& Hutrerer, R. (1962), Exp. Molec. Pathol. 1, 113-121. 15. de Duve, C., Pressman, B. C., Gianetto, R., Wattiaux, R. \& Appelarans, F. (1955), Biochem. J. 60, 604-617. - 16. Platt, D. \& Katzenmeier, U. (1970), Arzneim. Forsch. (Drug
Res.) 20, 258-261. - 17. Gianetro, R. \& DE Duve, C. (1955), Biochem. J. 59, 433-438. - 18. WATtiauX, R. \& DE Duve, C. (1956), Biochem. J. 63, 606-608. - 19. FrSKe, C. H. \& SubBarow, Y. (1925), J. Biol. Chem. 66, 375-400. - 20. van Hoof, F. \& Hers, H. G. (1968), European J. Biochem. 7, 34-44. 21. Anson, M. L. (1938), J. Gen. Physiol. 22, 79-89. - 22. Buddecke, E., Reich, G. \& Stein, U. (1966), Hoppe-Seyler's Z. Physiol. Chem. 347, 192-206. - 23. Matheson, A. T. \& Tatrrie, B. L. (1964), Canad. J. Biochem. 42, 95-103. - 24. Beisenherz, G., Boltze, H. J., Bücher, Th., Czok, R., Garbade, K. H., Meyer-Arendt, E. \& Pfleiderer, G. (1953), Z. Naturforsch. 86, 555-577. - 25. BERGMEYER, H. U. \& BERNT, E. (1962a) in Methoden det enzymatischen Analyse (Bergmeyer, H. U. ed.) 837-842, Verlag Chemie, Weinheim. - 26. BERGMEYER, H. U. \& BERNT, E. (1962b) in 1. c. (25) 846-851. 27. GERLACH, U. (1962), in 1. c. (25) 761-764. - 28. STEIN, U., Heissmeyer, H., ZummermanN, W. \& Lesch, R. (1971), Klin. Wschr. 49, 1271-1274. - 29. Herssmeyer, H., Stein, U. \& Strasser, K. (1971), Blut 23, 228-232. - 30. DE Duve, C., Wattraux, R. \& Wiвo, M. (1962), Biochem. Pharmacol. 9, 97-116. - 31. Beaufay, H., Campenhout, E. \& de Duve, C. (1959), Biochem. J. 73, 617-623. - 32. WerssmanN, G. \& Dingle, J. T. (1961), Exptl. Cell. Res. 25, 207-210. - 33. Suematsu, T., Iwaburi, N. \& Kotzumi, T. (1970), Biochem. Biophys. Acta 201, 378-380. 